\title{
Could BiPAP Cause Air in the Right Atrium?
}

\author{
BiPAP Sağ Atriyumdaki Havanın Nedeni Olabilir mi?
}

Burcu Akkok', Muhammed Çiftçioğlu², Akif Özcan'

\section{Abstract}

Air embolism refers to the entry of air into the venous or arterial system via direct conduction and pressure difference. The most common causes are iatrogenic, and are observed to be related to surgical and invasive procedures. The consequences of air embolisms depend on the air volume and the velocity of air entry. The clinical presentations may vary from asymptomatic course to shock. Emergency treatments include the provision of hemodynamics, oxygen support and positioning, and hyperbaric oxygen therapy in selected cases. In the present study we investigate the cause of the development of a venous air embolism in a patient on bilevel positive airway pressure (BiPAP) ventilation at home due to chronic respiratory failure and resorption in the short term without hyperbaric oxygen therapy.

Key words: Air embolism, BiPAP, latrogenic, Hyperbaric oxygen therapy.

\section{Özet}

Hava embolisi, havanın, direk ileti ve basınç farkı yoluyla venöz veya arteryel sisteme girmesi olarak tanınlanmaktadır. En sık görülen nedenleri iyatrojenik olup yapılan cerrahi ve invazif işlemlere bağlı olduğu görülmüştür. Hava embolisinin sonuçları hava hacmine ve havanın giriş hızına bağlıdır. Kliniği asemptomatik seyirden şoka giden tabloya kadar değişkenlik gösterebilir. Acil tedavi yöntemi ise hemodinaminin sağlanması, oksijen desteği ve pozisyon vermedir ve seçili olgularda hiperbarik oksijen tedavisidir. Bu olgu sunumunda kronik solunum yetmezliği nedeni ile evde bilevel pozitif hava yolu basıncı (BiPAP) kullanan hastada gelişen venöz hava embolisinin nedenlerini ve hiperbarik oksijen tedavisi verilmeden kısa dönemde rezorbe olduğunu göstermeyi amaçladık.

Anahtar Sözcükler: Hava embolisi, BiPAP, lyatrojenik, Hiperbarik oksijen tedavisi.
'Department of Pulmonary Medicine, Sütçü İmam University, Kahramanmaraş, Turkey

${ }^{2}$ Department of Internal Medicine, Sütçü İmam University, Kahramanmaraş, Turkey
'Sütçü İmam Üniversitesi Tıp Fakültesi, Göğüs Hastalıkları Anabilim Dalı, Kahramanmaraş

${ }^{2}$ Sütçü İmam Üniversitesi Tıp Fakültesi, İç Hastalıkları Anabilim Dalı, Kahramanmaraş

Submitted (Başvuru tarihi): 25.02.2021 Accepted (Kabul tarihi): 05.05.2021

Correspondence (iletişim): Burcu Akkok, Department of Pulmonary Medicine, Sütçü İmam University, Kahramanmaraş, Turkey

e-mail: bkaraokur@hotmail.com 
Air embolism is a potentially life-threatening event that may occur within the venous or arterial system depending on the entry site, and is a rare complication of invasive medical or surgical procedures $(1,2)$. The consequences of air embolism depend on the amount of air entering the bloodstream, the rate at which it enters and which bloodstream (venous or arterial) it enters. Arterial air embolisms can occur as a complication of lung biopsy, arterial catheterization or cardiopulmonary bypass. Emergency management involves placing the patient in the high flow oxygen and right lateral decubitus position. A venous air embolism can occur during pressurized venous infusions or catheter manipulation, and emergency treatment involves placing the patient on high-flow oxygen and in the left lateral decubitus and/or Trendelenburg position.

\section{CASE}

An 86-year-old male patient was admitted to the emergency room with abdominal pain, dizziness, fainting and short-term vision loss. He had a known diagnosis of hypertension, diabetes mellitus and heart failure, and was using BiPAP at home due to chronic respiratory failure. Upon entry to the emergency room, his vital signs were blood pressure, arterial 90/60 mmhg, and his room air oxygen saturation, measured by pulse oximetry, was 92 93\%. The arterial blood gas examined revealed below 2 It/min oxygen, $\mathrm{PH}: 7.5 \mathrm{PCO} 2: 46.7 \mathrm{mmHg}$ PO2: 88 $\mathrm{mmHg}$ and Sp02: $98 \%$. Among the laboratory findings, the leukocyte count was high, at 11000, CRP: $17 \mathrm{mg} / \mathrm{L}$ (0-8) and Creatine $1.95 \mathrm{mg} / \mathrm{dL}$. A computed tomography (CT) guided pulmonary angiography was planned for the pulmonary embolism, but when the calculated glomerular filtration rate of the patient was low, a non-contrast computed tomography was performed. In the resulting tomography, the left subclavian vein, the vena cava at the level of the thoracic inlet, the right atrium and the pulmonary truncus were leveled, and the linear air spaces in the anterior neighborhood of the right main pulmonary artery and findings were suggestive of pulmonary fibrosis (Figure 1) Air volume was calculated as $7-8 \mathrm{~mL}$, although no air spaces were observed in the left pulmonary artery, or in the pulmonary artery segment and the subsegment branches. Cardiology consultation was requested for the patient for the assessment of cardiac functions, and the ejection fraction was calculated as 50-55\%. Abdominal and cranial tomographies were also performed on the patient with suspected air embolism, but no pathology was detected. The patient was taken to the internal intensive care unit for close follow-up. Inotropic treatment was started due to a hypotensive course. Oxygen was given through a mask, and the patient was placed in the left lateral decubitus position. A control thoracic CT taken three days later revealed the air areas to have markedly resorbed (Figure 2). During follow-up, inotropic treatment was terminated after the patient progressed to normotensive.

\section{DISCUSSION}

Air embolisms can develop on the venous or arterial side of the circulatory system. Generally, venous air embolism can be well tolerated. In humans, 200-500 mL of air given at $100 \mathrm{~mL} / \mathrm{sec}$ has been defined as acutely fatal ( $\sim 3-5 \mathrm{~mL} / \mathrm{kg}$ ) (3). Which pathway arises depends largely on the volume of gas deposited in the right ventricle. If the embolism is large (about $5 \mathrm{ml} / \mathrm{kg}$ ), there may be a complete outlet obstruction due to the inability to detension the ventricular wall from the right ventricle. This can lead rapidly to right-sided heart failure and sudden cardiovascular collapse. Less volume venous air embolism, on the other hand, may lead to a decrease in cardiac output, hypotension, myocardial and cerebral ischemia, and even death. The entry of air into pulmonary circulation may cause pulmonary vasoconstriction, the release of inflammatory mediators, bronchoconstriction, and an increase in ventilation/perfusion mismatch. (2) The measured air embolism in our case was calculated as 7-8 $\mathrm{mL}$. The adverse effects of air embolism depend heavily on the volume of the embolism and its delivery rate, with small acute volumes being generally well tolerated, while larger volumes have significant effects on the cardiovascular, pulmonary and cerebral systems. Upon admission, the patient presented here complained of dizziness, abdominal pain and short-term vision loss. No neurological pathology was identified upon examination. In previous studies air embolism is most often attributed to sitting position operations, neurosurgical interventions, varicose surgery, gynecological interventions, central venous catheter insertion or air in fluid sets, hemodialysis or high-pressure mechanical ventilation applications (2).

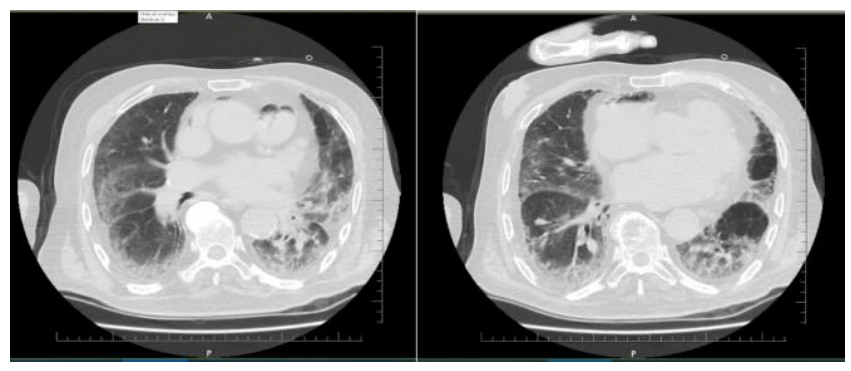

Figure 1: Air spaces leveled in the pulmonary trunk and right atrium 


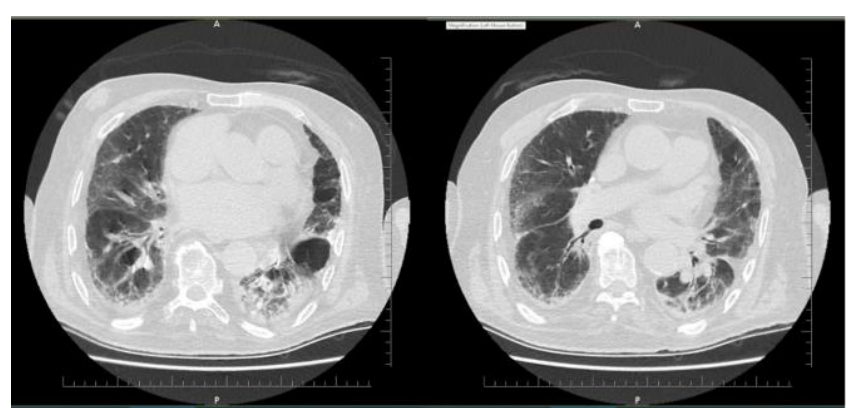

Figure 2: Control lung tomography after 3 days

When the current case was questioned, no history of intervention was ascertained. Although there are cases with air embolism after high-pressure mechanical ventilation applications, a case of cerebral embolism after BiPAP use has been detected in the literature. (4-7) Previous studies have reported the application of positive endexpiratory pressure (PEEP) for the prevention of air embolisms $(2,8)$. Since the patient in the present study was not detected with subcutaneous emphysema or pneumomediastinum, the air embolism was not attributed to the use of BiPAP. Following an evaluation, it was thought that the air may have developed iatrogenically during the routine vascular access upon entry to the first emergency room, and since the embolism amount was not too much and the clinical course did not worsen, the patient was followed up with mask oxygen, and the embolism was subsequently resorbed after 3 days.

\section{CONCLUSION}

Air embolisms are mostly attributable to iatrogenic reasons, and are a clinical condition that can change their clinical course depending on the duration of entry and the quantity of air. Air embolisms should be considered in cases of unexplained dyspnea, hypotension and neurological symptoms, and the necessary examinations and treatments should be planned accordingly.

\section{CONFLICTS OF INTEREST}

None declared.

\section{AUTHOR CONTRIBUTIONS}

Concept - B.A., M.Ç., A.Ö.; Planning and Design - B.A., M.Ç., A.Ö.; Supervision - B.A., M.Ç., A.Ö.; Funding M.Ç.; Materials - M.Ç., A.Ö., U.K., A.I.; Data Collection and/or Processing - B.A.; Analysis and/or Interpretation B.A.; Literature Review - B.A., M.Ç.; Writing - B.A.; Critical Review - B.A., M.Ç.

\section{YAZAR KATKILARI}

Fikir - B.A., M.Ç., A.Ö.; Tasarım ve Dizayn - B.A., M.Ç., A.Ö.; Denetleme - B.A., M.Ç., A.Ö.; Kaynaklar - M.Ç.; Malzemeler - M.Ç., A.Ö.; Veri Toplama ve/veya İşleme B.A.; Analiz ve/veya Yorum - B.A.; Literatür Taraması B.A., M.Ç.; Yazıyı Yazan - B.A.; Eleştirel İnceleme - B.A., M.Ç.

\section{REFERENCES}

1. Muth CM, Shank ES. Gas embolism. N Engl J Med 2000; 342:476-82. [CrossRef]

2. Mirski MA, Lele AV, Fitzsimmons L, Toung TJ. Diagnosis and treatment of vascular air embolism. Anesthesiology 2007; 106:164-77. [CrossRef]

3. Feil M. Preventing central line air embolism. Am J Nurs 2015; 115:64-9. [CrossRef]

4. Huang HJ, Lei S, Yang L, Jin LM. Systemic air embolism in a fungal pneumonia patient with lung cavities formation and review of literature. Chin J Traumatol 2019 Oct; 22:308-310. [CrossRef]

5. Gursoy S, Duger C, Kaygusuz K, Ozdemir Kol I, Gurelik B, Mimaroglu C. Cerebral arterial air embolism associated with mechanical ventilation and deep tracheal aspiration. Case Rep Pulmonol 2012; 2012:416360. [CrossRef]

6. Weaver LK, Morris A. Venous and arterial gas embolism associated with positive pressure ventilation. Chest 1998; 113:1 132-4. [CrossRef]

7. Rivara CB, Chevrolet JC, Gasche Y, Charbonney E. Fatal brain gas embolism during non-invasive positive pressure ventilation. BMJ Case Rep 2008; 2008:bcr0620080163 [CrossRef]

8. Perkins NA, Bedford RF. Hemodynamic consequences of PEEP in seated neurological patients--implications for paradoxical air embolism. Anesth Analg 1984; 63:42932. [CrossRef] 